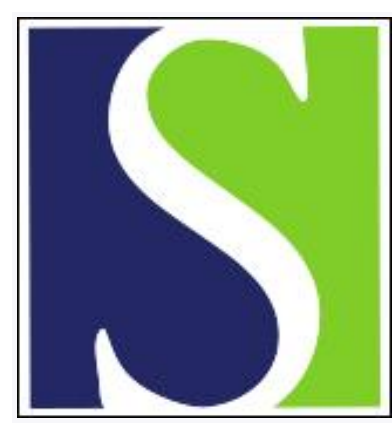

Scand J Work Environ Health 1989;15(1):30-37

https://doi.org/10.5271/sjweh.1885

Issue date: Feb 1989

Risk of lung, larynx, pharynx and buccal cavity cancers among carbon electrode manufacturing workers.

by Moulin JJ, Wild P, Mur JM, Lafontaine M, Lefer M, Mercier-Gallay M, Villemot P, Whebi V, Coulon JP

Affiliation: National Institute for Research and Safety, Vandoeuvre, France.

This article in PubMed: www.ncbi.nlm.nih.gov/pubmed/2922586 


\title{
Risk of lung, larynx, pharynx and buccal cavity cancers among carbon electrode manufacturing workers
}

\author{
by Jean J Moulin, MD, ${ }^{1}$ Pascal Wild, PhD, ${ }^{1}$ Jean M Mur, MD, ${ }^{1}$ Michel Lafontaine, PhD, ${ }^{1}$ \\ Monique Lefer, MD, ${ }^{2}$ Monique Mercier-Gallay, MD, ${ }^{3}$ Pierre Villemot, MD, ${ }^{3}$ \\ Vincent Whebi, MD, ${ }^{2}$ Jean $\mathrm{P}$ Coulon, $\mathrm{MD}^{2}$
}

\begin{abstract}
MOULIN JJ, WILD P, MUR JM, LAFONTAINE M, LEFER M, MERCIER-GALLAY M, VILLEMOT P, WHEBI V, COULON JP. Risk of lung, larynx, pharynx and buccal cavity cancers among carbon electrode manufacturing workers. Scand $J$ Work Environ Health 1989;15:30-37. Among workers employed in factories producing carbon graphite products the risk of cancer due to exposure to polycyclic aromatic hydrocarbons was estimated. In one cohort (plant A), a cancer incidence study was carried out; the number of cases were not significantly increased for lung cancers [ 7 cases, standardized incidence ratio (SIR) 79] or for cancers of the upper respiratory and alimentary tract (10 cases, SIR 103). In another cohort (plant B), a mortality study was carried out; neither the mortality from lung cancer [13 deaths, standardized mortality ratio (SMR) 118] nor that from upper respiratory and alimentary tract cancers (10 deaths, SMR 125) was significantly higher than expected. Within each cohort, a case-referent study was carried out. In plant $\mathrm{A}$ the odds ratios were high but nonsignificant for lung cancers (odds ratio 3.42) and upper respiratory and alimentary tract cancers (odds ratio 2.19) and they showed a nonsignificant relationship with duration of exposure. In plant $\mathrm{B}$, the odds ratios were low for every cancer site.
\end{abstract}

Key terms: benzo(a)pyrene, coal-tar pitch, cohort study, epidemiology, nested case-referent study, oral cavity cancers, polycyclic aromatic hydrocarbons, respiratory cancer.

The increased risk of lung cancer in humans as a result of exposure to chemicals, especially in the occupational environment, is either well known or suspected for several substances $(1-4)$. These exposures have been investigated in many epidemiologic and experimental studies undertaken to confirm or clarify the risks of cancer (5). Reviews of these studies are continually carried out by the International Agency for Research on Cancer (IARC), whose recent publications have been focused on the products derived from coal $(6-8)$. Indeed the industrial processes which use coal and its byproducts generate diverse polycyclic aromatic hydrocarbons (PAH), whose carcinogenous potential is suspected $(2,6,9-12)$. This pollution is often observed in factories where coal is gasified, in cokeworks, in iron and steel foundries, and in coal-tar distilleries, as well as in other plants which use coal by-products $(2,7$, 8).

The binding qualities of coal tar and coal-tar pitch explain their wide use in industry, mainly for (i) the manufacture of electrodes for the production of aluminum, (ii) the manufacture of pitch briquettes for industrial and domestic heating, (iii) the formulation of products used in road surfacing and the roofing of flat-

\footnotetext{
I National Institute for Research and Safety, Vandoeuvre Cédex, France.

2 Pechiney.

Societe des Electrodes et Refractaires de Savoie.
}

Reprint requests to: Dr JJ Moulin, Service d'Epidémiologie, Institut National de Recherche et de Sécurité, BP 27, 54501 Vandoeuvre Cédex, France. topped buildings, (iv) the impregnation of refractory bricks used in furnaces and blast furnaces, and (v) protection and waterproofing treatments for pipes and tanks. All these activities have in common the handling and heating of coal-tar pitch and therefore the release of PAH.

The IARC monographs state that there is sufficient evidence that certain exposures in the coke production industry and in coal gasification are carcinogenic to humans and that there is limited evidence of carcinogenicity to humans in the aluminum production industry and in iron and steel founding. Among the substances recognized for their carcinogenic risks (group 1) by IARC are, in particular, coal tar, coal-tar pitch, and soot (5). However the processes which use pitch as a primary material have not yet been precisely evaluated because these diverse activities have not yet given rise to a sufficient number of epidemiologic studies to allow a well-founded opinion.

This publication presents the results of an epidemiologic study focused on the risks of lung, larynx, pharynx, and buccal cavity cancers in relation to the production of electrodes and other carbon products manufactured with the use of coal-tar pitch as a binder.

\section{Materials and methods}

\section{Plant description}

The study included two plants (factories A and B) located in southeastern France. The manufactured 
products were electrodes used in electrometallurgy or in the aluminum industry; the electrodes weighed several tons each. Figure 1 shows the manufacturing processes, which consist of mixing raw materials, forming the crude paste, and then baking it. In addition, impregnation and graphitization were used in plant A only. During these different steps, handling the products used (coal-tar pitch in particular) and heating them to high temperatures may lead to the release of PAH in the form of dust during stocking and grinding or of vapors during baking, impregnation and graphitization, or of both dust and vapors during mixing and shaping. Plant B was set up in 1897 and plant $\mathrm{A}$ in 1895, but the manufacture of graphite electrodes in plant A has been taking place only since 1950 .

\section{Exposure measurements}

Data on past environmental exposure to benzo(a)pyrene $(\mathrm{BaP})$ were not available. In order to assess the present exposure, an environmental survey was carried out in 1983-1984. Atmospheric samples were collected on glass-fiber filters (Whatmann type GF/C). The PAH are either adsorbed on different sorts of dust or condensed to a solid state and can therefore be collected with a particulate sampling method. Two types of equipment were used. Personal samplers (Rotheröe Mitchell L2C) were carried by the operators for about half a shift $(4 \mathrm{~h})$. The filter diameters were $25 \mathrm{~mm}$, and the flow rate was $2 \mathrm{l} / \mathrm{mn}$. Stationary samplers were used to measure the general ambient atmosphere (Merlin Gerin APA 13 or Chaix Meca). They were equipped with filters $150 \mathrm{~mm}$ in diameter, and the flow rate was about $30 \mathrm{l} / \mathrm{mn}$.

After the sampling, the chromatographic profile and concentrations of several four- to six-cycle $\mathrm{PAH}$, including $\mathrm{BaP}$ for which there is a specific recommendation in France (ie, the mean value of BaP in the air must not exceed $150 \mathrm{ng} / \mathrm{m}^{3}$ ), were determined with high-performance liquid chromatography (HPLC). After benzene extraction with the Soxhlet apparatus, the PAH were separated and quantified with HPLC [ $\mathrm{C}_{18}$ reversed-phase column (length $25 \mathrm{~cm}$, internal diameter $4 \mathrm{~mm}$ ), elution by methanol at a flow rate of $1 \mathrm{ml} / \mathrm{min}$, detection by fluorimetry $(\lambda \mathrm{Exc}=365 \mathrm{~nm}$, $\lambda \mathrm{Em}=420 \mathrm{~nm})$ and by ultraviolet absorbance $(\lambda \mathrm{ab}=$ $284 \mathrm{~nm})]$.

\section{Cohort definition}

The data used for the historical follow-up studies were collected by the physicians of the companies according to the availability of the sources of information. Consequently, a cancer incidence study was carried out in plant A over a 11-year period from 1975 to 1985 , while mortality data were taken into account in plant B throughout a 28-year period from 1957 to 1984 . The cohorts included all male workers employed on 1 January 1975 in plant A and on 1 January 1957 in plant B. These dates were chosen because of the availabili-

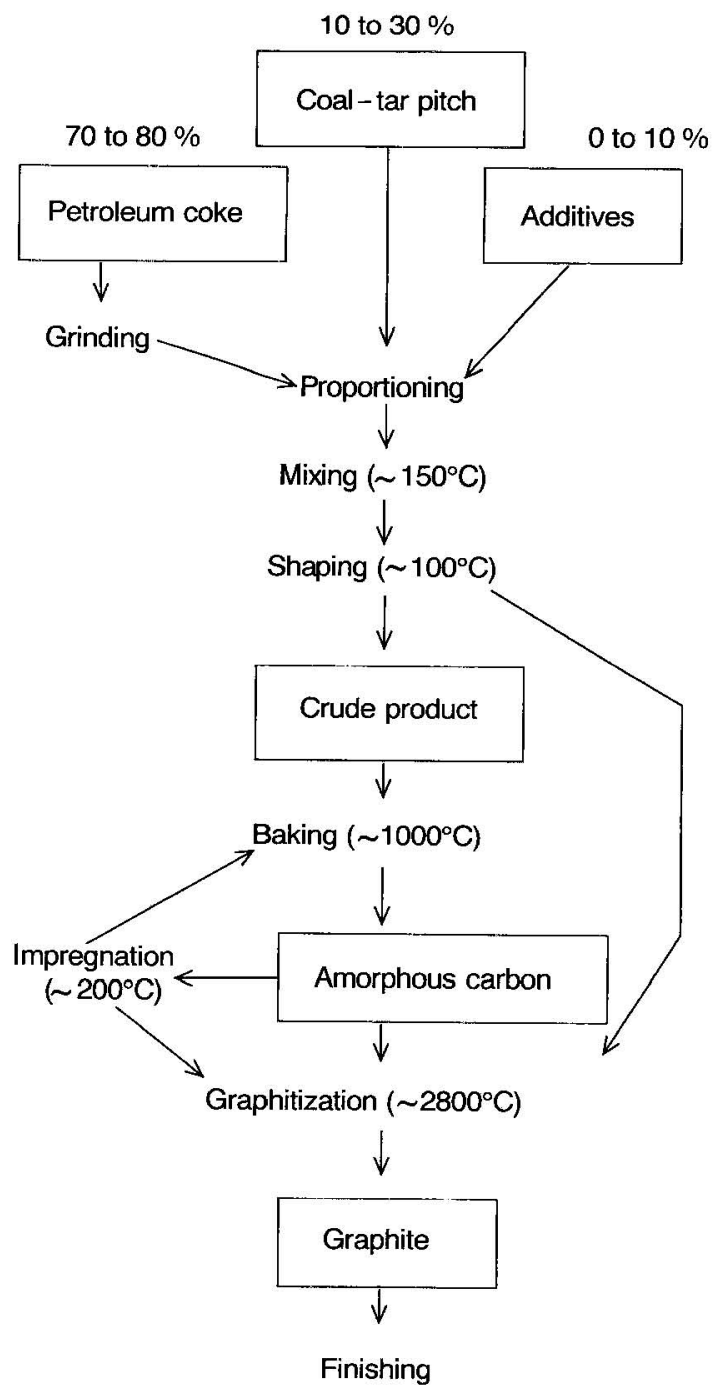

Figure 1. The manufacturing processes.

ty of medical information collected by the industrial physicians. The end of the follow-up was 31 December 1985 in plant A and 31 December 1984 in plant B. In addition all male workers hired by each factory during the follow-up period were included in the study.

\section{Sources of data}

The personnel office provided the following information for each worker: name, date and place of birth, dates of hire and resignation. Data on tobacco smoking were also supplied for most of the plant A workers. Detailed work histories were not available for all the workers of the two cohorts. For the identification of possible links between occupational exposures and respiratory cancers, occupational history and specific job descriptions were recorded only for the men 
selected for the case-referent study. There was no cancer incidence register in the district where plant A was located. Thus some diagnoses of cancer, such as skin cancers, whose prognosis is usually not too bad might be unknown. For plant $B$, the vital status of the workers no longer at the factory was ascertained either from the administrative records of the plant or from the registry offices of their birthplaces. Causes of deaths were given by the attending physicians, since death certificates cannot be used for mortality surveys in France.

\section{Statistical methods}

External comparisons. Each member of the cohorts contributed to the person-years at risk from the date of hire until the end of the follow-up or until the date of death if deceased. The workers lost to follow-up were assumed to be alive at the end of the study. The expected numbers were computed with two sets of references rates. It has already been mentioned that no cancer incidence rates were available for the general population of the district where plant A was located. Thus expected numbers were calculated with the use of incidence rates of another district, also located in southeastern France, not very far from plant A (13). This register gave mean incidence rates for men for the period 1979-1981. We checked that the age-adjusted cancer mortality rates of these two districts did not differ markedly. We computed the expected numbers of diagnoses for each cancer site by multiplying these rates by the person-years (five-year age groups). The expected numbers of deaths in plant $\mathbf{B}$ were calculated with the use of the national French population death rates, subdivided by cause, sex, age (fiveyear groups), and calendar time (one-year periods). The ratios of observed to expected diagnoses of cancer [standardized incidence ratio $=$ SIR $(\%)$ ], or death [standardized mortality ratio $=$ SMR $(\%)$ ] were calculated and their $95 \%$ Poisson confidence intervals $(95 \% \mathrm{CI})$ determined.

Case-referent study. In order to take into account specific job exposures to $\mathrm{PAH}$, we carried out a casereferent study. The cases were persons who had died of lung cancer or of upper respiratory and alimentary tract (ie, pharynx, larynx, buccal cavity) cancer in plant $B$ or persons who had been affected by the same types of cancer in plant A. For each case, three referents were chosen at random from within the cohort, matched by sex and year of birth, as well as by smoking habits in plant A (nonsmokers, smokers, smoking habits unknown). The referents were chosen from subjects who had never been affected by respiratory cancer. A few referents who died before the date of diagnosis of the corresponding case in plant $\mathrm{A}$ or before the date of death of the corresponding case in plant $\mathrm{B}$ were excluded from the statistical analysis. The work histories of the cases and the referents were known since the year of first employment. Each workshop they had worked in was given an exposed or unexposed status.

The results of this study are expressed as the odds ratio $(\mathrm{OR})$ values of the exposed workers as compared to those never exposed. The OR estimates and their variances were obtained by the conditional logistic regression fitted by the maximum likelihood method, and thus matching and the variable number of referents were taken into account (14). Smoking habits were not included in the analysis because this confounding factor was accounted for by the matching procedure when it was available (plant $A$ ) and was unknown for plant B.

PAH exposure was analyzed in three different ways. In a first analysis, the OR values of the workers who had been exposed for at least one year during their job history (ever exposed) were calculated; this group of workers was compared to never exposed workers (other manual or office workers). A second analysis took into account the length of exposure according to the following three groups: those exposed from 1 to 10 years, those exposed from 11 to 20 years, and those exposed for more than 20 years. The trend test was carried out by fitting a recoded factor based on these four groups (those never exposed and the three exposed groups) and by testing significance using the score statistic (14). A complementary analysis included the latency period by considering as exposed only those subjects exposed for five years or more along with a latency period of 10 years or more (time lapse between the date of the first exposure and the date of diagnosis in plant $\mathrm{A}$ and the date of death in plant B). These workers were compared to the never exposed ones, those with exposure of $<5$ years and/or a latency period of $<10$ years being excluded.

For each referent, the length of exposure to PAH and the length of the latency period from the beginning of exposure were taken into account until the year of diagnosis of the corresponding case in plant $\mathrm{A}$ and until the year of death of the corresponding case in plant B.

\section{Results}

\section{Exposure measurements}

Fifty-two samplings were carried out. The atmospheric concentrations of $\mathrm{BaP}$ are summarized in table 1 . The PAH atmospheric levels were higher on the whole in plant $\mathrm{A}$ (BaP concentrations between 340 and 12000 $\left.\mathrm{ng} / \mathrm{m}^{3}\right)$ than in plant $\mathrm{B}(\mathrm{BaP}$ concentrations between 15 and $\left.740 \mathrm{ng} / \mathrm{m}^{3}\right)$. According to these values and to values in other similar factories (15), electrode manufacturing plants are among the highly polluted sectors of industry, such as cokeworks and factories producing coal agglomerates. Contrary to other similar plants where the highest values were observed during preparation and shaping (the emission consists mainly of particulate $\mathrm{PAH}$ ), the pollution was 
Table 1. Benzo(a)pyrene (BaP) concentrations according to workshop and plant.

\begin{tabular}{|c|c|c|c|c|c|c|}
\hline \multirow{3}{*}{ Workshop } & \multicolumn{3}{|c|}{ Plant A } & \multicolumn{3}{|c|}{ Plant B } \\
\hline & \multirow{2}{*}{$\begin{array}{l}\text { Number of } \\
\text { samples }\end{array}$} & \multicolumn{2}{|c|}{$\mathrm{BaP}\left(\mathrm{ng} / \mathrm{m}^{3}\right)$} & \multirow{2}{*}{$\begin{array}{l}\text { Number of } \\
\text { samples }\end{array}$} & \multicolumn{2}{|c|}{$\mathrm{BaP}\left(\mathrm{ng} / \mathrm{m}^{3}\right)$} \\
\hline & & Mean & Range & & Mean & Range \\
\hline \multicolumn{7}{|l|}{ Preparation } \\
\hline $\begin{array}{l}\text { Area samplers } \\
\text { Personal samplers }\end{array}$ & $\begin{array}{l}2 \\
2\end{array}$ & $\begin{array}{l}2600 \\
3200\end{array}$ & $\begin{array}{l}2200-3000 \\
1400-5000\end{array}$ & $\begin{array}{l}4 \\
3\end{array}$ & $\begin{array}{l}610 \\
160\end{array}$ & $\begin{array}{r}490-740 \\
15-360\end{array}$ \\
\hline \multicolumn{7}{|l|}{ Shaping } \\
\hline $\begin{array}{l}\text { Area samplers } \\
\text { Personal samplers }\end{array}$ & $\begin{array}{l}1 \\
1\end{array}$ & $\begin{array}{l}2200 \\
2200\end{array}$ & $\begin{array}{l}2200 \\
2200\end{array}$ & $\begin{array}{l}3 \\
3\end{array}$ & $\begin{array}{r}430 \\
60\end{array}$ & $\begin{array}{r}390-500 \\
20-100\end{array}$ \\
\hline \multicolumn{7}{|l|}{ Baking } \\
\hline $\begin{array}{l}\text { Area samplers } \\
\text { Personal samplers }\end{array}$ & $\begin{array}{r}10 \\
5\end{array}$ & $\begin{array}{r}780 \\
1900\end{array}$ & $\begin{array}{l}340-2400 \\
590-4100\end{array}$ & $\begin{array}{l}3 \\
1\end{array}$ & $\begin{array}{l}270 \\
570\end{array}$ & $\begin{array}{c}180-320 \\
570\end{array}$ \\
\hline \multicolumn{7}{|l|}{ Impregnation } \\
\hline $\begin{array}{l}\text { Area samplers } \\
\text { Personal samplers }\end{array}$ & $\begin{array}{l}3 \\
4\end{array}$ & $\begin{array}{l}5600 \\
3900\end{array}$ & $\begin{array}{l}1900-12000 \\
2300-6200\end{array}$ & $\dot{.}$ & $\dot{.}$ & . \\
\hline \multicolumn{7}{|l|}{ Graphitization } \\
\hline $\begin{array}{l}\text { Area samplers } \\
\text { Personal samplers }\end{array}$ & $\begin{array}{l}3 \\
4 \\
\end{array}$ & $\begin{array}{l}1050 \\
2800 \\
\end{array}$ & $\begin{array}{l}420-2100 \\
590-5300 \\
\end{array}$ & . & . & $\dot{.}$ \\
\hline \multicolumn{7}{|l|}{ Total } \\
\hline $\begin{array}{l}\text { Area samplers } \\
\text { Personal samplers }\end{array}$ & $\begin{array}{l}19 \\
16\end{array}$ & $\begin{array}{l}1900 \\
2700\end{array}$ & $\begin{array}{l}340-12000 \\
590-6200\end{array}$ & $\begin{array}{r}10 \\
7\end{array}$ & $\begin{array}{l}460 \\
170\end{array}$ & $\begin{array}{r}180-740 \\
15-570\end{array}$ \\
\hline
\end{tabular}

Table 2. Observed and expected cases of cancer from 1975 to 1985 among the 1302 workers of plant A.

\begin{tabular}{|c|c|c|c|c|}
\hline Cancer sites ${ }^{a}$ & $\begin{array}{l}\text { Observed } \\
\text { number }\end{array}$ & $\begin{array}{l}\text { Expected } \\
\text { number }^{\mathrm{b}}\end{array}$ & $\begin{array}{l}\text { Standardized } \\
\text { incidence } \\
\text { ratio }\end{array}$ & $\begin{array}{c}95 \% \\
\text { confidence } \\
\text { interval }\end{array}$ \\
\hline Malignant neoplasms $(140-209)$ & 38 & 43.92 & 87 & $61-119$ \\
\hline Buccal cavity, pharynx, larynx $(140-149,161)$ & 10 & 9.73 & 103 & $49-189$ \\
\hline Esophagus $(150)$ & - & 1.88 & 0 & $0-196$ \\
\hline Stomach (151) & 2 & 1.58 & 127 & $15-457$ \\
\hline Colon (153) & 4 & 2.57 & 156 & $42-398$ \\
\hline Rectum (154) & 1 & 2.20 & 45 & $1-253$ \\
\hline Liver (155) & - & 0.73 & 0 & $0-503$ \\
\hline Pancreas (157) & 2 & 0.71 & 282 & $33-1017$ \\
\hline Trachea, bronchus, lung (162) & 7 & 8.82 & 79 & $32-163$ \\
\hline Prostate $(185)$ & 1 & 2.07 & 48 & $1-269$ \\
\hline Testes (186) & 3 & 0.53 & 566 & $117-1655$ \\
\hline Bladder (188) & - & 1.92 & 0 & $0-192$ \\
\hline Other urinary (189) & 2 & 1.17 & 171 & $21-617$ \\
\hline Brain (191) & 1 & 0.76 & 132 & $4-733$ \\
\hline Leukemia and lymphatic system (200-209) & 1 & 2.90 & 34 & $1-192$ \\
\hline Other or unspecified sites & 4 & & & \\
\hline
\end{tabular}

a Code of the International Classification of Diseases (eighth revision) in parentheses.

b The expected numbers were calculated with the use of the Isere Cancer Register (13).

homogeneous in the workshops of factories A and B. Pollution levels from coal-tar pitch vapors during impregnation were of the same order as during preparation and shaping.

\section{Cohort study}

The cohort from plant A included 1302 workers. Due to the fact that they left the plant because they resigned, were dismissed, or were transferred, 153 men $(11.8 \%)$ were lost to the follow-up, ie, cancer diagnosis could not be ascertained. The observed and expected numbers of cancer cases are shown in table 2 . The overall cancer incidence was slightly lower than expected, with 38 cases observed compared with 43.9 expected. Simi- larly, the number of lung cancer cases was lower than expected ( 7 observed, 8.8 expected). The observed number of upper respiratory and alimentary tract cancers $(\mathrm{N}=10)$ was equal to the number expected $(N=9.7)$. No case of bladder cancer occurred. The only significant excess concerned three cases of cancer of the testes (all observed in 1985) when compared with 0.53 expected (SIR 566, $95 \%$ CI 117-1655).

In the cohort from plant $\mathrm{B}$, which included a similar number of workers $(\mathrm{N}=1115)$, the vital status was unknown for 150 workers $(13.5 \%)$ who were born abroad. During the survey period, 164 deaths were recorded. As shown in table 3, the number of deaths occurring in this cohort was slightly lower than expected (SMR 82). Mortality from diseases of the cir- 
Table 3. Observed and expected causes of death from 1957 to 1984 among the 1115 workers from plant B.

\begin{tabular}{|c|c|c|c|c|}
\hline Causes of death ${ }^{a}$ & $\begin{array}{l}\text { Observed } \\
\text { number }\end{array}$ & $\begin{array}{l}\text { Expected } \\
\text { numberb }\end{array}$ & $\begin{array}{l}\text { Standardized } \\
\text { mortality } \\
\text { ratio }\end{array}$ & $\begin{array}{l}95 \% \\
\text { confidence } \\
\text { interval }\end{array}$ \\
\hline All causes $(000-999)$ & 164 & 198.93 & 82 & $70-96$ \\
\hline Undetermined cause & 8 &.$^{c}$ & $\cdots$ & . \\
\hline Circulatory system $(390-458)$ & 40 & 56.36 & 71 & $51-97$ \\
\hline Respiratory system $(460-519)$ & 4 & 10.50 & 38 & $10-98$ \\
\hline Cirrhosis of the liver (571) & 9 & 11.82 & 76 & $35-145$ \\
\hline Accidents, poisoning, violence (E 800-999) & 26 & 27.40 & 95 & $62-139$ \\
\hline Malignant neoplasms $(140-209)$ & 59 & 53.97 & 109 & $83-141$ \\
\hline $\begin{array}{l}\text { Buccal cavity, pharynx, larynx }(140-149,161) \\
\text { Esophagus }(150) \\
\text { Stomach }(151) \\
\text { Colon }(153) \\
\text { Rectum }(154) \\
\text { Liver }(155) \\
\text { Pancreas (157) }\end{array}$ & $\begin{array}{r}10 \\
1 \\
3 \\
2 \\
2 \\
4 \\
1\end{array}$ & $\begin{array}{l}7.99 \\
4.18 \\
4.01 \\
3.18 \\
1.77 \\
\cdots c \\
\cdots c\end{array}$ & $\begin{array}{r}125 \\
24 \\
75 \\
63 \\
113 \\
\cdots \\
\cdots\end{array}$ & $\begin{array}{r}60-230 \\
1-133 \\
15-219 \\
8-227 \\
14-408 \\
\cdots\end{array}$ \\
\hline $\begin{array}{l}\text { Trachea, bronchus, lung }(162) \\
\text { Prostate (185) } \\
\text { Testes }(186)\end{array}$ & $\begin{array}{r}13 \\
3 \\
-\end{array}$ & $\begin{array}{r}11.05 \\
2.93 \\
\ldots \mathrm{c}\end{array}$ & $\begin{array}{l}118 \\
102 \\
\cdots\end{array}$ & $\begin{array}{c}63-201 \\
21-299 \\
\ldots\end{array}$ \\
\hline Bladder (188) & 3 & 1.55 & 194 & $40-566$ \\
\hline $\begin{array}{l}\text { Other urinary }(189) \\
\text { Brain }(191)\end{array}$ & $\frac{-}{4}$ & $\begin{array}{l}\ldots \mathrm{c} \\
\ldots \mathrm{c}\end{array}$ & $\begin{array}{l}\cdots \\
\cdots\end{array}$ & $\begin{array}{l}. \\
\ldots\end{array}$ \\
\hline Leukemia and lymphatic system (200-209) & 4 & 3.20 & 125 & $34-320$ \\
\hline Other or unspecified sites & 9 & & . & . \\
\hline
\end{tabular}

a Code of the International Classification of Diseases (eighth revision) in parentheses.

b The expected numbers were calculated with the use of the national mortality rates for French men.

c National rates not available.

Table 4. Number of cases and referents, the odds ratios, and the $95 \%$ confidence intervals (obtained by conditional logistic regression) according to exposure and latency. ( $\mathrm{CD}=$ International Classification of Diseases, eighth revision)

\begin{tabular}{|c|c|c|c|c|c|c|c|c|}
\hline & \multicolumn{4}{|c|}{$\begin{array}{l}\text { Lung } \\
\text { (ICD 162) }\end{array}$} & \multicolumn{4}{|c|}{$\begin{array}{l}\text { Pharynx, larynx, buccal cavity } \\
\text { (ICD } 140-149,161)\end{array}$} \\
\hline & \multicolumn{2}{|c|}{ Exposed/unexposed } & \multirow{2}{*}{$\begin{array}{l}\text { Odds } \\
\text { ratio }\end{array}$} & \multirow{2}{*}{$\begin{array}{c}95 \% \\
\text { confidence } \\
\text { interval }\end{array}$} & \multicolumn{2}{|c|}{ Exposed/unexposed } & \multirow{2}{*}{$\begin{array}{l}\text { Odds } \\
\text { ratio }\end{array}$} & \multirow{2}{*}{$\begin{array}{c}95 \% \\
\text { confidence } \\
\text { interval }\end{array}$} \\
\hline & Cases & Referents & & & Cases & Referents & & \\
\hline \multicolumn{9}{|l|}{ Plant A } \\
\hline $\begin{array}{l}\mathrm{OR}_{1}^{\mathrm{a}} \\
\mathrm{OR}_{2}^{\mathrm{b}}\end{array}$ & $\begin{array}{l}6 / 1 \\
5 / 1\end{array}$ & $\begin{array}{r}13 / 8 \\
8 / 7\end{array}$ & $\begin{array}{l}3.42 \\
3.55\end{array}$ & $\begin{array}{l}0.35-33.68 \\
0.36-35.21\end{array}$ & $\begin{array}{l}8 / 2 \\
5 / 2\end{array}$ & $\begin{array}{l}18 / 10 \\
11 / 7\end{array}$ & $\begin{array}{l}2.19 \\
2.26\end{array}$ & $\begin{array}{l}0.42-11.54 \\
0.24-21.28\end{array}$ \\
\hline \multicolumn{9}{|l|}{ Plant B } \\
\hline $\begin{array}{l}\mathrm{OR}_{1}^{\mathrm{a}} \\
\mathrm{OR}_{2}{ }^{\mathrm{b}}\end{array}$ & $\begin{array}{l}6 / 7 \\
4 / 7\end{array}$ & $\begin{array}{l}21 / 12 \\
13 / 10\end{array}$ & $\begin{array}{l}0.49 \\
0.21\end{array}$ & $\begin{array}{l}0.12-2.02 \\
0.03-1.78\end{array}$ & $\begin{array}{l}4 / 6 \\
4 / 6\end{array}$ & $\begin{array}{l}17 / 10 \\
11 / 12\end{array}$ & $\begin{array}{l}0.44 \\
0.80\end{array}$ & $\begin{array}{l}0.10-2.02 \\
0.16-3.96\end{array}$ \\
\hline
\end{tabular}

a $\mathrm{OR}_{1}=$ exposure $\geq 1$ year versus never exposed.

b $\mathrm{OR}_{2}=$ exposure $\geq 5$ years and latency time $\geq 10$ years versus never exposed.

culatory system was also significantly lower than expected (SMR 71, $95 \%$ CI 51-97), as was mortality from diseases of the respiratory system (4 observed deaths, SMR 38, $95 \%$ CI 10-98). The overall cancer mortality did not significantly differ from that expected, nor did the deaths from lung cancer (SMR 118) or from upper respiratory and alimentary tract cancers (SMR 125). The three deaths from bladder cancer were more than the expected number, but not significantly so (SMR 194, $95 \%$ CI 40-566).

\section{Case-referent study}

The subjects considered as never exposed were essentially manual workers present in workshop areas with no known exposure to PAH; only a few of them (4\%) were office workers. Table 4 shows the OR values for the ever exposed workers $\left(\mathrm{OR}_{1}\right)$ and for a duration of exposure of $\geq 5$ years along with a latency period of $\geq 10$ years $\left(\mathrm{OR}_{2}\right)$ versus the unexposed. Table 5 gives the OR values according to the duration of exposure and the results of the trend test. In plant $A$, the OR values were high both for upper respiratory and alimentary tract cancers $\left(\mathrm{OR}_{1} 2.19, \mathrm{OR}_{2} 2.26\right)$ and for lung cancer $\left(\mathrm{OR}_{1} 3.42, \mathrm{OR}_{2} 3.55\right)$. The $\mathrm{OR}$ values increased with the duration of exposure, although this trend was not statistically confirmed. They were the highest for workers with the longest exposure $(>20$ years) (OR 4.07 for lung cancer, OR 3.85 for upper respiratory and alimentary tract cancers). Contrary to what was observed in plant $A$, the $O R$ values were all 
Table 5. Number of exposed cases and referents, the odds ratios, and the $95 \%$ confidence intervals (obtained by conditional logistic regression) according to the duration of exposure and the P-value of the trend test. (ICD = International Classification of Diseases, eighth revision)

\begin{tabular}{|c|c|c|c|c|c|c|c|c|}
\hline \multirow{3}{*}{$\begin{array}{l}\text { Duration of } \\
\text { exposure }\end{array}$} & \multicolumn{4}{|c|}{$\begin{array}{l}\text { Lung } \\
\text { (ICD 162) }\end{array}$} & \multicolumn{4}{|c|}{$\begin{array}{l}\text { Pharynx, larynx, buccal cavity } \\
\text { (ICD } 140-149,161)\end{array}$} \\
\hline & \multicolumn{2}{|c|}{ Exposed } & \multirow{2}{*}{$\begin{array}{l}\text { Odds } \\
\text { ratio }\end{array}$} & \multirow{2}{*}{$\begin{array}{c}95 \% \\
\text { confidence } \\
\text { interval }\end{array}$} & \multicolumn{2}{|c|}{ Exposed } & \multirow{2}{*}{$\begin{array}{l}\text { Odds } \\
\text { ratio }\end{array}$} & \multirow{2}{*}{$\begin{array}{c}95 \% \\
\text { confidence } \\
\text { interval }\end{array}$} \\
\hline & Cases & Referents & & & Cases & Referents & & \\
\hline \multicolumn{9}{|l|}{ Plant $A$} \\
\hline $\begin{array}{l}\text { Unexposed } \\
1-10 \text { years } \\
11-20 \text { years } \\
\geq 21 \text { years } \\
\text { Trend test }(P)\end{array}$ & $\begin{array}{l}1 \\
2 \\
2 \\
2\end{array}$ & $\begin{array}{l}8 \\
5 \\
5 \\
3\end{array}$ & $\begin{array}{l}2.90 \\
2.91 \\
4.07\end{array}$ & $\begin{array}{c}0.18-46.61 \\
0.19-45.78 \\
0.32-51.00 \\
0.27\end{array}$ & $\begin{array}{l}2 \\
3 \\
2 \\
3\end{array}$ & $\begin{array}{r}10 \\
7 \\
7 \\
4\end{array}$ & $\begin{array}{c}2.17 \\
1.63 \\
3.85\end{array}$ & $\begin{array}{c}0.31-14.99 \\
0.18-14.34 \\
0.44-33.64 \\
0.27\end{array}$ \\
\hline \multicolumn{9}{|l|}{ Plant $B$} \\
\hline $\begin{array}{l}\text { Unexposed } \\
1-10 \text { years } \\
11-20 \text { years } \\
\geq 21 \text { years } \\
\text { Trend test }(P)\end{array}$ & $\begin{array}{l}7 \\
3 \\
2 \\
1\end{array}$ & $\begin{array}{r}12 \\
12 \\
4 \\
5\end{array}$ & $\begin{array}{c}0.38 \\
0.88 \\
0.32\end{array}$ & $\begin{array}{l}0.07-2.16 \\
0.12-6.38 \\
0.02-4.29 \\
\quad 0.48\end{array}$ & $\begin{array}{l}6 \\
0 \\
2 \\
2\end{array}$ & $\begin{array}{r}10 \\
6 \\
2 \\
9\end{array}$ & $\begin{array}{c}. \\
0.00 \\
1.74 \\
0.36\end{array}$ & $\begin{array}{c}\cdots \\
0.24-12.95 \\
0.04-3.42 \\
0.50\end{array}$ \\
\hline
\end{tabular}

lower than one in plant $\mathrm{B}$, and no relationship was observed with the duration of exposure. However, in both plants, none of these values (OR and $P$ values of the trend test) was statistically significant. The OR values do not conflict with the values of the atmospheric samplings carried out in 1983-1984 (table 1). In plant B, the least polluted factory, the OR values were low, while in factory A the OR values were high and increased with the length of exposure. This finding will be discussed further.

\section{Discussion}

The manufacturing of electrodes involves handling coal-tar pitch; baking it at about $1000^{\circ} \mathrm{C}$, which releases almost all the volatile substances; and graphitization at about $2800^{\circ} \mathrm{C}$, which in certain cases is likely to generate PAH. During this activity, measurements of atmospheric BaP have been carried out in Sweden (2). The levels were less than $1300 \mathrm{ng} / \mathrm{m}^{3}$ near the baking furnaces. Excessive values (19 000-40000 ng/m $\mathrm{m}^{3}$ ) were observed in the impregnation workshops, but in the graphitization workshop only three values out of 24 exceeded $100 \mathrm{ng} / \mathrm{m}^{3}$. A Russian publication (16) reported concentrations between 195 and $4730 \mathrm{ng} / \mathrm{m}^{3}$ in several factories. These values are of the same magnitude as those of the present study (table 1).

Several epidemiologic studies have been carried out in tar distilleries and in industries using coal-tar pitch, mainly aluminum production, and the manufacture of briquettes and roofing. Among tar distillation workers, Henry et al (17) found a nonsignificant excess of bladder cancer deaths. More recently, unlike a French study (18) whose results were negative for lung cancers and upper respiratory and alimentary tract cancers, a British investigation (19) concluded that an excess of lung and bladder cancer mortality was work-related. In the aluminum manufacturing industry, several epidemiologic studies have been carried out; these studies have been reported in detail by IARC, which concluded that there was limited evidence of lung and bladder cancer risk (7). Another French study was negative (20). In the manufacture of briquettes, several publications have reported clinical cases of skin cancer $(21-26)$. The study published by Henry in 1946 (22) reported a crude mortality rate of $504 / 10^{6}$ due to scrotal cancer in workers engaged in briquette production, whereas the national rate was $4.2 / 10^{6}$. In French publications $(21,23-26)$, no incidence evaluation has been attempted, but it was underlined that the skin cancers were generally situated on the face and occurred after a long duration of exposure (10-30 years) in plants where high pollution levels had been measured (27). Among roofers and slaters (28-32) and lens polishers (33) significantly increased risks of lung cancer, and to a less extent of upper respiratory tract and digestive cancers, have been observed. Finally, several case-referent studies have shown urinary tract tumors in relation to "pitch" exposure, without the exposure being clearly stated (34-36).

Companies working with graphite products have not yet been the subject of numerous epidemiologic studies. An investigation based on the mutagenic activity of carbon electrode workers' urine has shown a relationship between exposure and mutagenic effect; smoking habits were taken into account (37). An American epidemiologic study carried out in 11 carbon products manufacturing plants has recently been published (38). The results do not indicate an adverse effect of coal-tar pitch exposure on mortality. Although the levels of PAH exposure in the workplace atmospheres were unknown, the authors suggested that these negative results could be explained either by the method's "low sensitivity to detect mortality excesses that may exist in small subgroups of the study population [p 349]," or by the "lower concentrations and therefore exposure to suspect carcinogen $\mathrm{PAH}$ due to 
the lower temperature to which coal tar pitch is heated [p 349]' (38).

In the present study, some limitations must be discussed before conclusions are drawn. The validity of the external reference used to calculate the expected numbers of cases in plant A cannot be assessed. In the same way, the SIR values might have been underestimated because of the lack of a local cancer register and because of the persons lost to follow-up. However, the SIR values did not differ markedly from 100 , except for cancers of the testes, which could be a random cluster, since no occupational factor has yet been pointed out. Both the low overall mortality observed in plant B and the significantly low SMR values for disease of the circulatory and respiratory system could be due to the "healthy worker effect." Furthermore, these low values could be partly explained by the lack of precision of causes of deaths ascertained after a long period and by the high percentage of subjects of unknown vital status.

The case-referent study carried out in plant B failed to reveal an association between cancer mortality and occupational exposure to PAH. On the contrary, in plant $A$, the $O R$ values were high and related to the duration of exposure, although not significantly. This result contrasts with the lower SIR values and raises the question of whether the data collection could have been biased (more exhaustive among the exposed workers than among the unexposed ones). We checked that this was not the case by carrying out a case-referent study using, as cases, cancers other than lung and upper respiratory and alimentary tract cancers. The $O R_{1}$ was 0.75 (13 exposed cases out of $21 ; 41$ exposed referents out of 59), the $\mathrm{OR}_{2}$ was 0.61 ( 7 exposed cases, 22 exposed referents), and the OR values were not related to the duration of exposure. In the matching procedure, smoking habits were taken into account for plant A only, while they were unknown for plant B. One can regret this lack of information because cigarette smoke contains PAH (39). Nevertheless smoking habits are unlikely to be a confounding factor in this study, since nothing seems to indicate a connection with occupational exposure to PAH.

These results are not in conflict with those of present atmospheric pollution (personal samplings). The means and the ranges of the BaP concentrations were the highest in plant $A$ (mean value $2700 \mathrm{ng} / \mathrm{m}^{3}$ ), while the corresponding data from factory $\mathrm{B}$ were much lower (mean value $170 \mathrm{ng} / \mathrm{m}^{3}$ ). However these pollution rates only reflect recent work conditions (the years 1983-1984), whereas the cancer cases may be due to exposure dating from much further back, 1934 in plant $A$ and 1911 in plant B. Thus it cannot be asserted that the classification of plants according to recent pollution measurements has remained the same throughout the last five decades. As a consequence their link with the observed risks must be considered with caution as it could be attributed to chance.
The low values of the OR estimates for plant B are unlikely to be attributable to differential smoking or exposure misclassification. It must therefore be considered as a random value. One can notice nevertheless that the $95 \%$ confidence intervals of the overall risk ratio contain values as high as two.

In conclusion, this study was focused on the risks of lung, larynx, pharynx, and buccal cavity cancers in relation to exposure to coal-tar pitch or to $\mathrm{PAH}$. The levels of risk were determined with both the duration of exposure and the latency period taken into account. The OR values and trend tests suggest a relationship between exposure and the occurrence of these cancers in one plant, but the results are negative for the other one. A definite conclusion about the risk of respiratory cancer for workers involved in the manufacture of carbon electrodes cannot therefore be reached. A further follow-up study is planned.

\section{References}

1. Higginson J, Muir CS. Détermination de l'importance des facteurs environnementaux dans le cancer humain: rôle de l'épidémiologie. Bull Cancer (Paris) 1977;64: 365-84.

2. Lindstedt $\mathrm{G}$, Sollenberg J. Polycyclic aromatic hydrocarbons in the occupational environment: with special reference to benzo(a)pyrene measurements in Swedish industry. Scand J Work Environ Health 1982;8:1-19.

3. Pike MC, Gordon RJ, Henderson BE, Menck HR, SooHoo J. Air pollution. In: Fraumeni JF, ed. Persons at high risk of cancer, an approach to cancer etiology and control. New York: Academic Press, 1975:225-39.

4. Sawicki E. Chemical composition and potential "genotoxic" aspects of polluted atmospheres. In: International Agency for Research on Cancer. Air pollution and cancer in man. Lyon: International Agency for Research on Cancer, 1977:127-57. (IARC scientific publication; no 16).

5. Vainio H, Hemminki K, Wilbourn J. Data on the carcinogenicity of chemicals in the IARC monographs programme. Carcinogenesis $1985 ; 6: 1653-65$.

6. International Agency for Research on Cancer. Polynuclear aromatic compounds: part 1, chemical environmental and experimental data. Lyon: International Agency for Research Cancer, 1983. (IARC monographs on the evaluation of the carcinogenic risk of chemicals to humans; vol 32.)

7. International Agency for Research on Cancer. Polynuclear aromatic compounds: part 3, industrial exposures in aluminum production, coal gasification, coke production, and iron and steel founding. Lyon: International Agency for Research on Cancer, 1984. (IARC monographs on the evaluation of the carcinogenic risk of chemicals to humans; volume 34 ).

8. International Agency for Research on Cancer. Polynuclear aromatic compounds: part 4, bitumens, coaltars and derived products, shale-oils and soots. Lyon: International Agency for Research on Cancer, 1985. (IARC monographs on the evaluation of the carcinogenic risk of chemicals to humans; vol 35.)

9. Everall JD, Dowd PM. Influence of environmental factors excluding ultra violet radiation on the incidence of skin cancer. Bull Cancer (Paris) 1978;65:241-8.

10. Kipling MD. Occupational considerations in carcinoma of the urogenital tract. Br J Hosp Med 1976;15:465-72.

11. Kipling MD, Waldron HA. Polycyclic aromatic hydrocarbons in mineral oil, tar, and pitch, excluding 
petroleum pitch. Prev Med 1976;5:262-78.

12. Kipling MD, Cooke MA. Soots, tars, oils as causes of occupational cancers. In: Searle CE, ed. Chemical carcinogens. 2nd edition. Washington, DC: American Cancer Society, 1984:165-74. (American Cancer Society monograph; vol 182.)

13. Menegoz F, Lutz JM. Le cancer dans l'Isère, 1979, 1980, 1981. Grenoble: Registre du Cancer de l'Isère, 1983.

14. Breslow NE, Day NE. The analysis of case-controls studies. In: Breslow NE, Day NE, ed. Statistical methods in cancer research; vol 1. Lyon: International Agency for Research on Cancer, 1980:247-79. (IARC scientific publication; no 32.)

15. Lafontaine $M$, Attenont $H$, Truy $S$. Emission d'hydrocarbures polycycliques aromatiques dans l'industrie productrice d'electrodes. Paris: Institut National de Recherche et de Sécurité, 1988:453-7. (Cahiers de Notes Documentaires de l'Institut National de Recherche et de Sécurité; vol 132.)

16. Konstantinov VG, Alikin PF, Ustyuzhanina ZV, Bessonova AP, Gorina VS. Resinous substances and Benzo(a)pyrene in the air environment of some industrial buildings of the Dniepr electrode plant. Chem Abstr 1979;91:43906.

17. Henry SA, Kennaway NM, Kennaway EL. The incidence of cancer of the bladder and prostate in certain occupations. J Hyg 1931;31:125-37.

18. Moulin JJ, Mur JM, Wild P, Demonchy A, Eloy E, Jeannot A. Etude épidémiologique de mortalité parmi les salariés d'une usine de distillation des goudrons de houille. Rev Epidemiol Sante Publique 1988;36:99-107.

19. Maclaren WM, Hurley JF. Mortality of tar distillation workers. Scand J Work Environ Health 1987;13: 404-11.

20. Mur MJ, Moulin JJ, Meyer-Bisch C, Massin N, Coulon JP, Loulergue L. Mortality of aluminium reduction plant workers in France. Int J Epidemiol 1987;16: 257-64.

21. Geraut C, Dumortier L, Dupuis C, Le Fur Y, Limasset $\mathrm{C}$, Moncelon B. Cancers et exposition professionnelle au brai de houille. Concours Med 1978;3097-102.

22. Henry SA. Cancer of the scrotum in relation to occupation. New York: Oxford University Press, 1946.

23. Manouvriez A. Maladies et hygiène des ouvriers travaillant à la fabrication des agglomérés de houille et de brai. Ann Hyg Publ Med Leg 1876;45:459-82.

24. Pierre F, Robillard J, Mouchel A. Tumeurs cutanées chez les ouvriers exposés au brai de houille. Arch Mal Prof Med Trav Secur Soc 1965;26:475-82.

25. Rault $C$. A propos de l'action cancérogène du brai de houille sur la peau, les voies aérodigestives supérieures et les poumons [Thèse Médecine]. Nantes (France): University of Nantes, 1981.

26. Samsoen M, Ksikes F, Tesseraud F, Cardonne R.
Pathologie du brai de houille, apects cliniques et épidémiologiques. Arch Mal Prof Med Trav Secur Soc 1981; $42: 49-50$.

27. Lafontaine M, Limasset JC. Exposition aux hydrocarbures polycycliques aromatiques dans l'industrie des ag glomérés de houille. Paris: Institut National de Recherche et de Sécurité, 1987:57-61. (Cahiers de Notes Documentaires de l'Institut National de Rechercher et de Sécurité; vol 126.)

28. Decouflé P, Stanislawczyk K, Houten L, Bross IDJ, Viadana $\mathrm{E}$. A retrospective survey of cancer in relation to occupation. Cincinnati, Ohio: US Department of Health, Education and Welfare, National Institute for Occupational Safety and Health, 1977.

29. Hammond CE, Selikoff IJ, Lawther PL, Seidman H Inhalation of benzo(a)pyrene and cancer in man. Ann NY Acad Sci 1976;271:116-24.

30. Menck HR, Henderson BE. Occupational differences in rates of lung cancer. J. Occup Med 1976;18:797-801.

31. Milham S. Occupational mortality in Washington State 1950-1979. Cincinnati, Ohio: National Institute for Oc cupational Safety and Health, 1982.

32. Silverstein M, Maizlish N, Park R, Mirer F. Mortality among workers exposed to coal tar pitch volatiles and welding emissions: an exercise in epidemiologic triage. Am J Public Health 1985;75:1283-7.

33. Wang JD, Wegman DH, Smith TJ. Cancer risks in the optical manufacturing industry. Br J Ind Med 1983;40: $177-81$.

34. Claude J, Kunze E, Frentzel-Beyme R, Paczkowski K, Schneider J, Schubert H. Life-style and occupational risk factors in cancer of the lower urinary tract. Am J Epidemiol 1986;124:578-89.

35. McLaughlin JK, Blot WJ, Mandel JS, Schuman LM Mehl ES, Fraumeni JF. Etiology of cancer of the renal pelvis. J Natl Cancer Inst 1983;71:287-91.

36. McLaughlin JK, Mandel JS, Blot WJ, Schuman LM, Mehl ES, Fraumeni JF. A population-based case control study of renal cell carcinoma. J Natl Cancer Inst 1984;72:275-84.

37. Pasquini R, Monarca S, Sforzolini GS, Conti R, Fagioli F. Mutagens in urine of carbon electrode workers. Int Arch Occup Environ Health 1982;50:387-95.

38. Teta MJ, Ott MG, Schnatter AR. Population based mortality surveillance in carbon products manufacturing plants. Br J Ind Med 1987;44:344-50.

39. Surgeon General. The health consequences of smoking, cancer. Washington, DC: US, Department of Health and Human Services, Office on Smoking and Health, 1982:181-236

Received for publication: 3 May 1988 